\title{
Pengaruh Organisasi Pembelajaran, Keterlibatan Karyawan Terhadap Komitmen dan Perubahan Organisasi Di RSJPDHK
}

\author{
Asti Kuwaitiningsih ${ }^{1}$. Iwan Kresna Setiadi , Acim Heri Iswanto ${ }^{3}$ \\ Universitas Pembangunan Nasional Veteran Jakart \\ astiku.nata@gmail.com¹, ikase25@gmail.com², h.iswanto@upnvi.ac.id². _
}

\section{ARTICLES \\ INFORMATION}

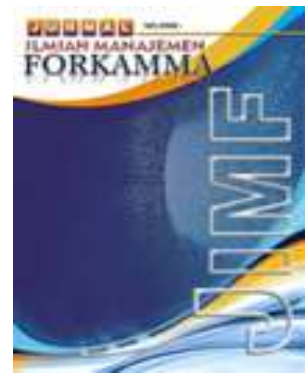

\section{JURNAL ILMIAH MANAJEMEN FORKAMMA}

Vol.4, No.3, Juli 2021

Halaman : $298-314$

(c) LPPM \& FORKAMMA

Prodi Magister Manajemen UNVERSITAS PAMULANG

ISSN (online) : 2599-171X

ISSN (print) : :2598-9545

\section{Keyword :}

Organisasi pembelajaran; keterlibatan karyawan; komitmen organisasi; perubahan organisasi.

JEL. classification : O15,

Contact Author :

PRODI

MAGISTER MANAJEMEN \& FORKAMMA UNPAM

JL.Surya Kencana No.1 Pamulang

Tangerang Selatan - Banten

Telp. (021) 7412566, Fax (021) 7412491 Email :

jurnalforkamma.unpam@gmail.com
Abstrak. Penelitian untuk mengetahui pengaruh organisasi pembelajaran, keterlibatan karyawan terhadap komitmen dan perubahan organisasi ini berada di institusi kesehatan, yaitu RS Jantung dan Pembuluh Darah Harapan Kita yang terletak di Slipi, Jakarta Barat. Penelitian menggunakan metode penelitian kuantitatif. Pengambilan data dilakukan melalui survey terhadap 100 responden merupakan karyawan yang bekerja di RS Jantung dan Pembuluh Darah Pembuluh Darah Harapan Kita. Seluruh responden merupakan sampel yang tersebar di seluruh unit kerja dengan menggunakan simple random sampling dan teknik analisisnya adalah metode PLS. Hasil penelitian menunjukkan bahwa Organisasi pembelajaran yang tidak signifikan dengan nilai p 0,078 terhadap komitmen organisasi. Keterlibatan karyawan yang signifikan dengan nilai $p 0,00$. Komitmen Organisasi sendiri memberikan pengaruh secara siginifikan dengan nilai $p \quad 0,024$ terhadap perubahan organisasi. Organisasi pembelajaran tidak memberikan pengaruh secara signifikan dengan nilai $p \quad 0,832$ terhadap perubahan organisasi.

Kata Kunci: Organisasi pembelajaran; keterlibatan karyawan; komitmen organisasi; perubahan organisasi.

Abstract. The research aimed to determine the effect of learning organizations, nurse involvement on commitment and organizational change in health institutions, namely the National Cardiovascular Center Harapan Kita (RSPDHK). All respondents are samples that are scattered throughout the nursing unit using simple random sampling and the analysis technique is using the PLS method. The results showed that the learning organization was not significant with a $p$ value of 0.078 on organizational commitment. The nurse involvement variable has a significant influence with $p$ value of 0.00 on organizational commitment. organizational commitment itself has a significant influence with a $p$ value of 0.024 on organizational change. the learning organization does not significantly influence the $p$ value of 0.832 on organizational change.

Keyword : Learning organization; employee engagement; organizational commitment; organizational change. 


\section{A. PENDAHULUAN}

Rumah sakit termasuk dalam sarana pelayanan dimana menyediakan kegiatan seperti kesehatan dan juga memiliki fungsi berupa tempat untuk melakukan pendidikan serta penelitian. Pelayanan yang berkualitas dalam hal kesehatan kepada masyarakat, membuat rumah sakit harus selalu mengikuti perkembangan informasi dan teknologi. Pelayanan kesehatan yang layak dapat memberikan kepuasan pada pasiennya. Kemajuan teknologi industri dalam segala bidang yang terus berkembang membuat sumber daya manusia dituntut agar terampil serta berkualitas untuk memenuhi tujuan organisasi. Sumber daya manusia sebagai faktor yang paling strategis dan paling bertanggungjawab dalam konteks maju mundurnya suatu organisasi. Oleh karenanya dalam rangka peningkatan efektivitas serta efisiensi suatu organisasi sebaiknya pengelolaan sumber daya manusia dapat dilakukan dengan baik.

Sejalan dengan perkembangan zaman maka persaingan pun bermunculan pada dunia dibidang kesehatan seperti rumah sakit sehingga wajib memanfaatkan sumber daya yang telah ada. Dimana kondisi tersebut akan banyak menuntut rumah sakit agar dapat dilakukan beberapa terobosan terbaru untuk menghadapi persaingan global. Dengan mengikuti kegiatan-kegiatan yang dibuat seperti seminar dan pelatihan untuk menambah wawasan menjadikan sumber daya manusia semakin berkualitas. Contoh rumah sakit yang berfungsi selain untuk pelayanan dalam hal kesehatan yaitu dapat berfungsi pula sebagai organisasi pendidikan dan penelitian untuk tenaga kesehatan di Jakarta adalah RSJPDHK. Organisasi yang mengkhususkan layanan kesehatan jantung serta merupakan rumah sakit pendidikan pada spesialis jantung dan pembuluh darah dari berbagai penjuru negeri. Untuk dapat meningkatnya kualitas pelayanan terhadap pasien maka rumah sakit memberikan pelatihan dan pendidikan bagi para karyawannya untuk semakin profesional.

Rumah sakit ini didirikan karena memiliki tujuan selain menyediakan kegiatan melayani pasien, dapat juga meneliti berbagai hal kesehatan. Pelayanan dalam bidang kesehatan merupakan upaya yang disediakan oleh suatu fasilitas kesehatan untuk pemeliharaan dan peningkatan kesehatan bagi masyarakat. Pelayanan dalam hal kesehatan yang bermutu adalah pelayanan yang berkualitas untuk setiap masyarakatnya.

Selain menjadi sarana pengobatan, rumah sakit juga berfungsi sebagai organisasi pembelajaran. Dimana para karyawannya terus melakukan pembelajaran yang bersinambungan dengan tujuan meningkatkan pengetahuan dengan tekonologi yang baru. Yakni menjadi tempat pendidikan dan pelatihan bagi masyarakat pada umumnya dan karyawan rumah sakit pada khususnya dibidang spesialis jantung dan pembuluh darah. "Organisasi pembelajaran merupakan tempat untuk melakukan proses belajar secara terus menerus baik secara individu maupun kelompok demi tercapainya tujuan organisasi" (Senge, 2006).

Dengan adanya hal tersebut maka diperlukan keterlibatan karyawan untuk menambah angka perubahan serta komitmen berorganisasi pada karyawan baik karyawan yang baru maupun yang lama. Keterlibatan karyawan dinilai mempunyai efek yang sangat dominan. Dimana karyawan sebagai sumber daya manusia utama yang satu bersama unsur lainnya saling berkaitan agar menghasilkan output bagi perusahaan tersebut. Untuk memberikan pelayanan kesehatan yang berkualitas maka diperlukan keterlibatan karyawan khususnya karyawan terhadap manajemen yang handal dengan memberikan pengetahuan, keterampilan dan pelatihan kepada setiap karyawan. Hal ini yang akan menjadi salah satu kunci untuk dapat maju dalam konteks kinerja dinamis di tempat kerja yang modern dari sebuah lembaga kesehatan.

RSJPDHK juga sebagai tempat pendidikan. Dimana bertujuan untuk menciptakan 
tenaga-tenaga professional yang ahli dalam bidang kesehatan spesialis jantung dan pembuluh darah. Rumah sakit yang memiliki fungsi sebagai organisasi pembelajar tentunya diperlukan manajemen sumber daya manusia dengan kualitas yang unggul didalam hal perencanaan, evaluasi kerja serta pelaksanaan kinerja. Rumah sakit pun harus selalu memperbaharui diri sesuai dengan perkembangan lingkungan serta terus berusaha menjadi semakin lebih baik. Organisasi pembelajaran dapat berjalan lancar maka sebaiknya diperlukan komitmen organisasi dalam prosesnya.

Perkembangan informasi dan teknologi dibidang kesehatan semakin pesat membuat kehidupan organisasi harus mengalami perubahan. Perubahan merupakan bagian dari suatu organisasi serta dijadikan tolak ukur berhasilnya seorang pemimpin dimana perubahan kearah yang lebih baik dijadikan potensi. Perubahan dalam organisasi kesehatan terjadi karena dampak globalisasi sehingga mengharuskan organisasi tersebut mampu untuk mengantisipasi dengan segala perkembangan yang terjadi. Perubahan ini membuat manajemen sumber daya manusia harus terlibat secara aktif agar mampu menciptakan keunggulan kompetitif dibandingkan dengan organisasi lainnya. Perubahan membutuhkan pengelolaan yang berkesinambungan.

Rumah sakit wajib bersikap profesional agar hasil kerja yang terbaik dapat diberikan dan kompetensi dapat ditingkatkan secara berkelanjutan. Sejalan visi dan dalam rangka menjalankan misi sebagai rumah sakit yang melaksanakan pelayanan dalam hal kardiovaskular yang berkualitas serta meningkatkan penelitian dan pengembangan teknologi cardiovascular kepada setiap pasiennya. Organisasi ini lebih memilih mempertahankan kualitas serta memberikan pelayanan yang terbaik agar pasien senantiasa merasa nyaman. Kinerja karyawan baik tenaga medis maupun non medis akan lebih ditekankan pada perubahan organisasi dalam pelaksanaan kebijakan rumah sakit ke arah yang lebih baik.

Perubahan organisasi didalam organisasi yakni rumah sakit bertujuan untuk mempertahankan kelangsungan hidup organisasi dalam jangka waktu pendek dan panjang. Disamping sebagai pelayanan kesehatan masyarakat, rumah sakit juga dituntut untuk siap terhadap perubahan baik internal dan eksternal. Perubahan tersebut dapat berupa pengembangan sumber daya manusia. Dimana saat ini tidak lagi bersifat fungsional namun lebih bersifat strategis. Pengembangan sumber daya manusia saat ini dipahami sebagai strategi dalam menyiapkan masing-masing individu pegawai untuk memikul tanggung jawab yang lebih besar dimasa yang akan datang dengan memberikan perhatian dan peluang yang lebih baik di saat ini.

Pentingnya komitmen organisasi didalam suatu organisasi agar dapat berkembang menjadi salah satu fenomena yang terjadi. Dengan adanya keterlibatan karyawan khususnya karyawan didalamnya diharapkan dapat memunculkan rasa memiliki serta bertanggungjawab terhadap organisasi yang besar sehingga mereka siap untuk perubahan ke arah yang positif demi memajukan pelayanan organisasi yang lebih baik lagi. Meskipun dalam melakukan perubahan akan banyak rintangan namun jika ditanggulangi bersama maka dapat dilalui.

Perubahan dalam organisasi memerlukan keberanian yang tinggi untuk dapat diakui oleh seluruh organisasi. Karena dalam melakukan perubahan akan ada tantangan sehingga setiap individu memerlukan salah satunya adalah rasa aman dan faktor ekonomi. Anggota suatu organisasi dapat terdiri dari beberapa kelompok tertentu, seperti karyawan. Dengan adanya keterlibatan karyawan maka perubahan yang diinginkan oleh organisasi yakni agar dapat menjadi tempat layanan kesehatan serta pendidikan yang terbaik di Indonesia segera tercapai. Jika dilihat berdasarkan penelitian, partisipasi karyawan berperan tinggi dalam melakukan perubahan organisasi. Namun masih banyak karyawan yang merasakan ketidaknyamanan dalam organisasi. Rasa aman serta ketidakpastian membuat beberapa diantara mereka menentang adanya 
perubahan. Penelitian yang dilakukan adalah untuk menganalisis dan membuktikan pengaruh organisasi pembelajaran terhadap komitmen organisasi, pengaruh keterlibatan karyawan terhadap komitmen organisasi, pengaruh komitmen organisasi terhadap perubahan organisasi, pengaruh organisasi pembelajaran terhadap perubahan organisasi, pengaruh keterlibatan karyawan terhadap perubahan organisasi.

\section{B. KAJIAN LITERATUR}

\section{Organisasi Pembelajaran}

Konsep organisasi pembelajaran yang dimaksud dalam penelitian ini adalah sebuah wadah atau organisasi dengan mengutamakan pendidikan atau pembelajaran yang berada dalam suatu organisasi agar pelayanan dapat lebih ditingkatkan menjadi optimal. Pengertian organisasi pembelajaran (Harper and Glew, 2008) "merupakan suatu perusahaan yang berkomitmen untuk meningkatkan kinerja perusahaan dengan menemukan hal-hal baru baru untuk dilakukan dan jalan atau cara yang baru untuk melakukan hal-hal tersebut. Pengetahuan yang tersimpan didalam dan diluar individu." Sedangkan (Senge, 2006) berpendapat, "organisasi pembelajar adalah organisasi dimana individu atau kelompok terus menerus memperluas kapasitas mereka untuk menciptakan hasil yang benar-benar mereka inginkan dan belajar melihat bersamasama secara menyeluruh. Alasan dasar untuk organisasi tersebut adalah bahwa dalam situasi perubahan yang cepat hanya mereka yang fleksibel, adaptif dan produktif yang dapat bertahan". "Sementara semua orang memiliki kapasitas untuk belajar, struktur dimana mereka harus berfungsi sering tidak konduksif untuk berefleksikan dan melibatkan mereka. Selanjutnya orang mungkin tidak memiliki alat serta ide-ide pembimbing untuk memahami situasi yang mereka hadapi. Organisasi yang terusmenerus akan memperluas kapasitas mereka untuk menciptakan masa depan mereka yang memerlukan perubahan pemikiran secara mendasar di kelompok anggotanya. Orang-orang berbicara tentang bagian dari sesuatu yang lebih besar dari diri mereka sendiri" (Senge, 2006).

\section{Keterlibatan Karyawan}

Dalam penelitian ini keterlibatan karyawan merupakan kategori karyawan non medis dimana karyawan juga bagian dari aset organisasi agar dapat menjalankan tujuan organisasi secara bersama. Keterlibatan karyawan adalah "suatu keadaan dimana karyawan yang terlibat secara langsung secara psikologi dengan pekerjaannya. Karyawan tersebut akan terlibat secara fisik, kognitif, maupun secara emosional selama menunjukkan performanya didalam bekerja" (Abrecht, 2010). Sedangkan (Robbins and Judge, 2008) mengemukakan "keterlibatan karyawan adalah keterlibatan individu dengan kepuasan dan antusiasme untuk pekerjaan yang dilakukan." Hal lain juga dikemukakan "bahwasanya karyawan yang engaged akan bekerja dengan semangat dan merasakan hubungan yang mendalam dengan perusahaan dimana mereka bekerja, mereka mendorong inovasi dan mendorong kemajuan organisasi. Ciri karyawan yang menunjukkan keterlibatan akan bekerja dengan usaha ekstra dan lebih dari apa yang diharapkan"(Gallup, 2008). Pada penelitian ini keterlibatan karyawan lebih ditekankan pada karyawan yang berprofesi sebagai karyawan di RSJPDHK. Keterlibatan karyawan bukan hanya dalam kegiatan kekaryawanan saja tetapi juga aktif terlibat dalam kegiatan manajemen, seperti adanya pelatihan, seminar dan pendidikan duna pengembangan diri dan pertumbuhan individu karyawan tersebut.

\section{Komitmen Organisasi}

Dalam suatu organisasi atau perusahaan terdapat individu atau karyawan yang 
memiliki ikatan emosional kepada perusahaan seperti dukungan moral dan memliki kemauan untuk mengabdi kepada perusahaan. "Komitmen organisasi merupakan sikap merefleksikan loyalitas karyawan pada organisasi dan proses berkelanjutan diaman anggota organisasi mengekspresikan perhatiannya terhadap organisasi dan keberhasilan serta kemajuan yang berkelanjutan" (Luthans, 2012). Sedangkan (Robbins and Judge, 2008) menjelaskan "bahwa komitmen organisasi adalah suatu keadaan dimana seorang karyawan memihak organisasi tertentu serta tujuan-tujuan dan keinginannya untuk mempertahankan keanggotaannya dalam organisasi tersebut." Menurut (Alwi, 2001) "komitmen organisasi adalah sikap karyawan untuk tetap berada dalam organisasi dan terlibat dalam upaya-upaya mencapai misi, nilai-nilai dan tujuan organisasi. Komitmen juga merupakan sebuah bentuk loyalitas yang lebih nyata yang dapat dilihat dari sejauh mana kontribusi karyawan dalam memberikan perhatian, gagasan, dan tanggungjawabnya untuk mencapai tujuan organisasi”.

\section{Perubahan Organisasi}

"Organisasi hanya dapat berjalan jika dapat melakukan perubahan. Setiap perubahan lingkungan yang terjadi harus dicermati karena keefektifan suatu organisasi yang tergantung pada sejauh mana organisasi dapat menyesuaikan diri dengan perubahan tersebut. (Robbins, 2003). Pada dasarnya semua perubahan yang dilakukan mengarah pada peningkatan efektifitas organisasi dengan tujuan mengupayakan perbaikan kemampuan organisasi dalam menyesuaikan diri terhadap perubahan lingkungan serta perubahan perilaku anggota organisasi. Perubahan organisasi dapat dilakukan pada struktur yang mencakup strategis dan system, teknologi, penataan fisik dan sumber daya manusia". Perubahan organisasi dapat terjadi jika semua telah tertata dengan baik.

\section{METODOLOGI PENELITIAN}

\section{Waktu Dan Tempat Penelitian}

Penelitian ini berlangsung di RSJPDHK yang beralamat di jalan Letnan Jenderal S. Parman Kav. 87 Slipi, Jakarta Barat. Dengan tujuan untuk mempelajari dan menganalisis tentang perubahan organisasi pada karyawan rumah sakit. Waktu pelaksanaan penelitian dilaksanakan mulai bulan Maret 2019 sampai dengan Desember 2019. RSJPDHK "merupakan rumah sakit khusus yang menjadi Pusat Rujukan Nasional untuk penanganan penyakit jantung dan pembuluh darah (cardiovascular)".

\section{Teknik Analisis Data}

Analisis inferensial didalam penelitian ini untuk metode yang digunakan adalah SEM. Dimana metode SEM menurut (Ghozali, 2014) "merupakan teknik analisis multivariate memungkinkan peneliti untuk menguji hubungan antar variabel untuk memperoleh gambaran menyeluruh mengenai keseluruhan model." Berdasarkan model dan hipotesa dalam penelitian ini, "teknik analisa yang digunakan untuk analisis data adalah Struktural Equation Modeling (SEM)." "Metode SEM merupakan alat statistik yang digunakan untuk menyelesaikan model bertingkat secara serempak yang mana tidak dapat diselesaikan oleh persamaan regresi linier". Metode SEM juga sebagai gabungan analisis regresi dan analisis faktor. "Dengan dilakukannya metode analisis dalam penelitian ini untuk menguji hipotesis dengan menganalisis data mentah yang telah dikumpulkan oleh responden. Proses analisis data analisis data merupakan proses yang sangat penting dalam suatu penelitian karena peneliti dapat memberikan makna yang bermanfaat dalam menyelesaikan masalah yang ada. Dalam penelitian ini metode SEM yang digunakan adalah pendekatan variance based SEM atau yang lebih dikenal 
sebagai Partial Least Square (PLS) denganmenggunakan software smartPLS dan Xistat". "Metode analisis PLS ini metode analisisnya tidak didasarkan pada banyaknya asumsi yang bermakna dan data tidak harus berdistribusi normal multivariate (indikator dengan skala kategori, ordinal, interval sampai rasio dapat digunakan pada model yang sama), serta sampel tidak harus besar" (Ghozali, 2014). "PLS (Partial Least Square) merupakan analisis persamaan struktural (SEM) berbasis varian yang secara simultan dapat dilakukan pengujian model pengukuran sekaligus pengukuran model struktural. Metode analisis PLS bersifat soft modeling karena tidak tidak mengamsusikan data untuk pengukuran skala tertentu yang berarti jumlah sampel dapat menjadi kecil yaitu dibawah 100 sampel".

Analisis metode SEM adalah sebagai representasi sistem yang diteliti seharusnya dapat menjelaskan perialku sistem mendekati kondisin riil. Dalam penelitian ini metode SEM yang digunakan adalah pendekatan Partial Least Square (PLS). Analisis PLS ini kemudian dikembangkan menjadi analisis WarpPLS. "Model ini pertama kali dikembangkan oleh Herman Wold. Model ini dikembangkan sebagai alternatif untuk situasi dimana dasar teori pada perancangan model lemah atau belum ditemukan dan atau terdapat indikator yang tidak memenuhi model pengukuran reflektif sehingga bersifat normatif. PLS selain dapat digunakan sebagai konfirmasi teori (uji hipotesis) juga dapat digunakan untuk membangun hubungan yang belum ada landasan teorinya atau untuk pengujian proposisi." Langkah-langkah analisis PLS dalam penelitian ini menurut (Solimun, 2018) adalah :

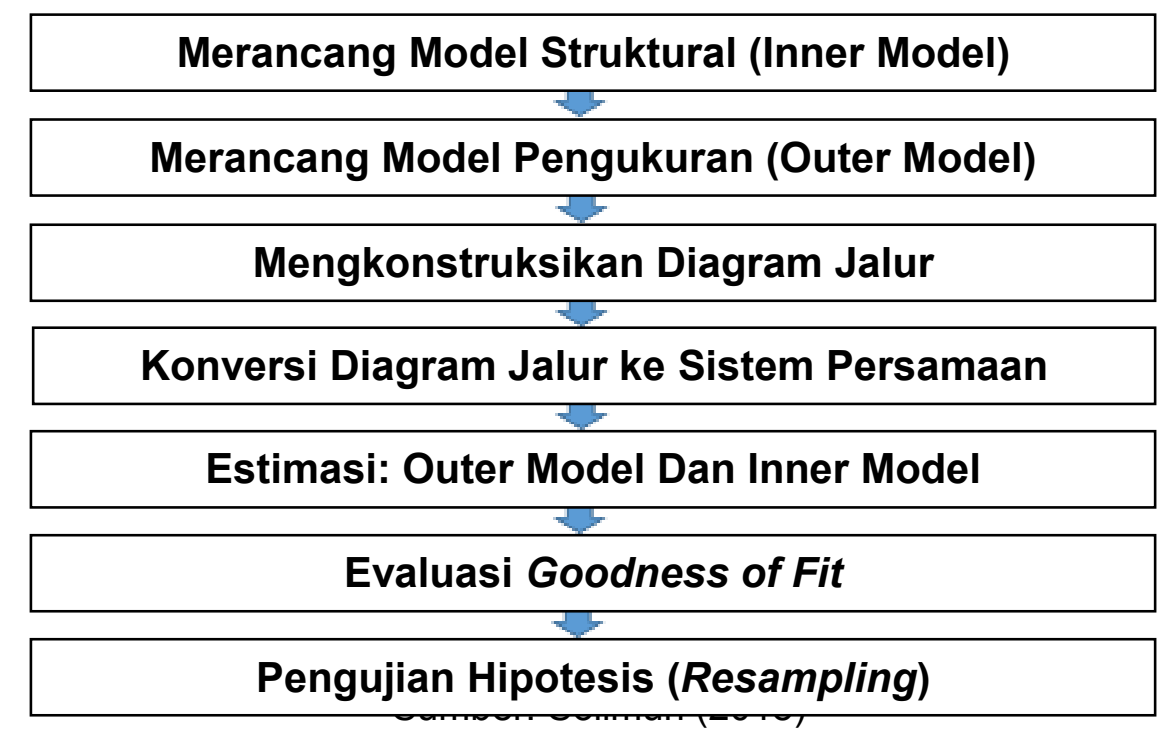

\section{HASIL DAN PEMBAHASAN}

"Pengumpulan data yang dilakukan dalam penelitian ini bertujuan untuk memperoleh data dan seluruh informasi. Berdasarkan permasalahan yang telah dikemukakan maka data-data yang disajikan dalam penelitian ini disajikan dalam bentuk pengumpulan data primer dan data sekunder" (Sugiyono, 2017). Responden dalam penelitian ini adalah karyawan di lingkungan RSJPDHK yang berprofesi sebagai karyawan sejumlah 100 orang. Data dikumpulkan melalui kuesioner yang dikirim melalui intranet ke nomor handphone masing-masing responden. Ketentuan sampel dalam penelitian adalah 100 responden (Ferdinand, 2006). Data responden mayoritas usia responden berada diantara usia 26 sampai dengan 35 tahun dengan persentase $34 \%$. Hal ini membuktikan bahwa pegawai yang bekerja sebagai karyawan di RSJPDHK 
merupakan pegawai-pegawai yang memiliki semangat bekerja dan minat akan pengetahuan yang tinggi serta menginginkan perubahan di dalam organisasi ke arah yang lebih baik.

Mayoritas responden berpendidikan Strata 1 yaitu sebesar $63 \%$ atau berjumlah 63 orang. Hal ini menunjukkan karyawan yang bekerja di RSJPDHK mayoritas memiliki pendidikan terakhir S1 kekaryawanan karena memprioritaskan Pendidikan dengan pengetahuan - pengetahuan yang intelektual yang cukup baik. mayoritas responden sebesar $32 \%$ atau yang berjumlah 32 orang yang memiliki masa kerja antara lebih dari 20 tahun. Hal ini menunjukkan bahwa RSJPDHK diisi oleh karyawan-karyawan yang sudah memiliki banyak pengalaman dan mereka yang memiliki loyalitas yang tinggi pada rumah sakit. menunjukkan mayoritas responden sebesar $31 \%$ atau 31 orang adalah karyawan dengan level kompetensi Competent. Hal tersebut menunjukkan bahwa karyawan di RSJPDHK adalah karyawan yang memiliki kompetensi yang handal dan berkualitas.

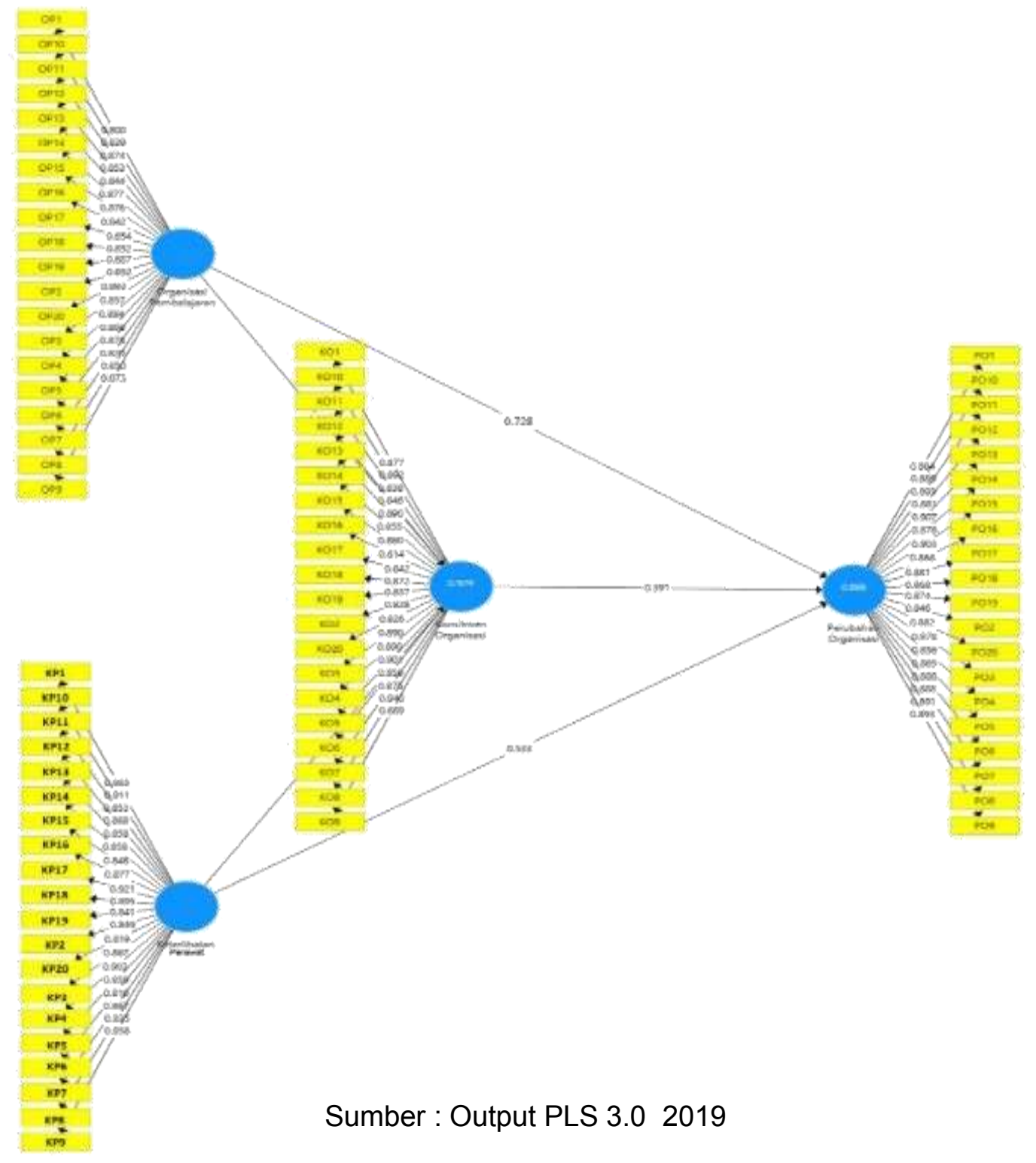

Gambar 1 Kosntruk Model 


\section{Uji Validitas Diskriminan}

(Ghozali, 2014) menyatakan "bahwa uji validitas digunakan untuk mengukur sah atau valid tidak suatu kuesioner. Suatu kuesioner dikatakan vallid jika pernyataan pada kuesioner mampu untuk mengungkapkan susatu yang akan diukur oleh kuesioner tersebut. suatu tes dapat dikatakan memiliki validitas yang tinggi jika tes tersebut menjalankan fungsi ukurnya atau memberikan hasil ukur yang tepat dan akurat sesuai dengan maksud dikenakannya tes tersebut."

Cara selanjutnya untuk melihat "discriminant validity adalah dengan melihat nilai square root of average variance extracted (AVE), Tujuannya untuk mengetahui valid atau tidaknya suatu indikator pada penelitian. Nilai yang disarankan adalah diatas 0,5 berikut hasil output sofware Smart-PLS 3.0 didapat nilai AVE dalam penelitian ini" :

Tabel 7. Average Variance Extracted (AVE)

\begin{tabular}{lc}
\hline & $\begin{array}{c}\text { Average Variance Extracted } \\
(\text { AVE) }\end{array}$ \\
\hline Keterlibatan Karyawan & 0,746 \\
\hline Komitmen Organisasi & 0,742 \\
\hline Organisasi Pembelajaran & 0,738 \\
\hline Perubahan Organisasi & 0,776 \\
\hline
\end{tabular}

Sumber : hasil olah data (2019)

Tabel 7 di atas "menunjukan nilai AVE di atas 0,746 untuk semua konstruk yang terdapat pada model penelitian. Berdasarkan tabel 4 diatas pada variabel Keterlibatan Karyawan memiliki nilai sebesar 0,746, variabel Komitmen Organisasi sebesar 0,742, variabel Organisasi Pembelajaran sebesar 0,738 dan variabel Perubahan Organisasi sebesar 0,776. Dengan hasil ini maka kuisioner yang digunakan oleh variabel Perubahan Organisasi, Keterlibatan Karyawan dan Organisasi Pembelajaran dinyatakan valid sebagai alat ukur variabel."

\section{Uji Reliabilitas PLS}

Langkah selanjutnya setelah diperoleh validitas dari masing-masing instrument pertanyaan pervariabel dilakukan uji reliabilitas. Uji reabilitas ini dapat dilihat dari hasil output software Smart-PLS 3.0 didapatkan nilai Composite Reliability dan Cronbach's Alpha masing - masing variabel konstruk sebagai berikut :

Tabel 8. Composite Reliability dan Cronbach's Alpha

Cronbach's Alpha Composite Reliability

\begin{tabular}{lll} 
Keterlibatan Karyawan & 0,982 & 0,982 \\
\hline
\end{tabular}




\begin{tabular}{lcc}
\hline Komitmen Organisasi & 0,982 & 0,983 \\
\hline Organisasi Pembelajaran & 0,981 & 0,983 \\
\hline Perubahan Organisasi & 0,985 & 0,986 \\
\hline
\end{tabular}

Sumber: Hasil Output PLS 3.0

Tabel 8 di atas menunjukkan "bahwa nilai composite reliability dan Cronbach's Alpha untuk semua konstruk adalah di atas 0,7 yang menunjukkan bahwa semua konstruk pada model yang diestimasi memenuhi kriteria. Pada variabel Keterlibatan Karyawan memiliki nilai composite reliability sebesar 0,983 dan nilai cronbach's alpha sebesar 0,982, variabel Komitmen Organisasi memiliki nilai composite reliability sebesar 0,983 dan nilai cronbach's alpha sebesar 0,982, variabel Organisasi Pembelajaran memiliki nilai composite reliability sebesar 0,983 dan nilai cronbach's alpha sebesar 0,981 , variabel Perubahan Organisasi memiliki nilai composite reliability sebesar 0,986 dan nilai cronbach's alpha sebesar 0,985. hal ini menunjukkan bahwa semua variabel memiliki reliabilitas yang sangat baik terhadap masing-masing konstruknya serta memenuhi persyaratan sesuai dengan tabel 6. Uji Reliabilitas menunjuk pada suatu pengertian bahwa instrumen yang digunakan dalam penelitian untuk memperoleh informasi yang digunakan dapat dipercaya sebagai alat pengumpulan data dan mampu mengungkap informasi yang sebenarnya dilapangan."

\section{Hasil Pengukuran Nilai R Square}

"Langkah selanjutnya adalah setelah seluruh butir pernyataan per variabel dinyatakan valid, seluruh variabel juga dinyatakan reliabel, maka langkah selanjutnya adalah menguji model struktural penelitian melalui uji R Square. Hasil output software Smart-PLS 3.0 terkait uji R square adalah sebagai berikut" :

Tabel 9. Nilai $R$ Square

\begin{tabular}{cc}
\hline & R Square \\
\hline Komitmen Organisasi & 0,929 \\
\hline Perubahan Organisasi & 0,888 \\
\hline
\end{tabular}

Sumber: Hasil Output PLS 3.0

Berdasarkan tabel 9 di atas, dapat diketahui bahwa besarnya $R$ Square (R2) Komitmen Organisasi adalah sebesar 0,929 dengan demikian menunjukan pengaruh antara Organisasi pembelajaran dan keterlibatan karyawan terhadap Komitmen Organisasi sebesar $92,9 \%$ dan sisanya sebesar $7,1 \%$ dipengaruhi oleh faktor lain atau variabel lainnya seperti motivasi, kinerja karyawan. Dan nilai $R$ Square Perubahan Organisasi sebesar 0,888 yang Organisasi pembelajaran, keterlibatan karyawan dan Komitmen Organisasi berpengaruh terhadap Perubahan Organisasi sebesar 88,8\% dan sisanya $11,2 \%$ dipengaruhi oleh variabel lain seperti faktor lingkungan dan perkembangan teknologi. 
Maka diketahui $t_{\text {tabel }}=1.985$ kemudian dihubungkan dengan derajat kesalahan $5 \%$ atau 0,05 .

Berdasarkan hasil pengolahan data untuk uji signifikasi (Uji t), diperoleh hasil sebagai berikut :

Tabel 10. Hasil Uji t-Statistik

\begin{tabular}{lccc}
\hline & $\begin{array}{c}\text { Original } \\
\text { Sample (O) }\end{array}$ & $\begin{array}{c}\text { T Statistics } \\
(\mid \mathrm{O} / \text { STDEV|) }\end{array}$ & P Values \\
\hline $\begin{array}{l}\text { Organisasi Pembelajaran -> } \\
\text { Komitmen Organisasi }\end{array}$ & 0,422 & 2,769 & 0,078 \\
\hline $\begin{array}{l}\text { Keterlibatan Karyawan -> } \\
\text { Komitmen Organisasi }\end{array}$ & 0,750 & 6,087 & 0,000 \\
\hline $\begin{array}{l}\text { Komitmen Organisasi -> } \\
\text { Perubahan Organisasi }\end{array}$ & 0,391 & 2,263 & 0,024 \\
\hline $\begin{array}{l}\text { Organisasi Pembelajaran -> } \\
\text { Perubahan Organisasi }\end{array}$ & 0,728 & 6,212 & 0,832 \\
\hline $\begin{array}{l}\text { Keterlibatan Karyawan -> } \\
\text { Perubahan Organisasi }\end{array}$ & 0,533 & 2,826 & 0,005 \\
\hline
\end{tabular}

Sumber: Hasil Output olah data (2019)

Pengaruh organisasi pembelajaran terhadap komitmen organisasi

Pada penelitian ini organisasi pembelajar menunjukan tidak berpengaruh secara signifikan terhadap komitmen organisasi dengan nilai T-statistik sebesar 2,769 hasil nilai P-Value 0,078 yang jauh lebih besar dari nilai alpha 0,05 pada taraf kepercayaan $95 \%$. Hal ini juga ditunjukkan dengan nilai original sampel yang positif yaitu sebesar 0,422 yang menunjukkan bahwa arah hubungan antara X1 dan $\mathrm{Y} 2$ adalah tidak positif. Pengaruh positif tersebut juga dapat dibuktikan dengan salah satu indikator pernyataan organisasi pembelajaran yang tidak memberikan pengaruh sangat kuat adalah kesediaan berbagi informasi terbaru tentang karyawanan pasien. Hasil relevan ini dengan kondisi di RSJPDHK dimana para karyawan tidak bersedia untuk berbagi informasi tentang karyawanan pasien yang ditanganinya kepada semua orang. Hal ini dikarenakan data kesehatan pasien bersifat rahasia (confidential) dan didalam pendidikan serta pelatihan dalam organisasi pembelajaran tenaga kesehatan atau karyawan diharap dapat menjaga kerahasiaan kesehatan pasiennya. Penelitian ini juga sejalan dengan hasil penelitian yang dilakukan oleh Monica Ida Uniati (2014) membuktikan "bahwa tidak adanya pengaruh langsung antara organisasi pembelajaran terhadap komitmen organisasi. Hal ini menunjukkan bahwa dalam organisasi pendidikan sebuah organisasi pembelajaran harus dapat memberikan kepuasan kerja para pekerjanya kepada organisasi sebelum dapat membangun komitmen pada organisasi."

Hasil penelitian ini juga tidak sejalan dengan penelitian yang dilakukan oleh (Atak and Erturgut, 2010) "menyatakan bahwa organisasi pembelajaran berpengaruh terhadap komitmen organisasi disebabkan faktor penting dalam organisasi pembelajaran memiliki 
banyak dampak pada layanan yang dianggap sangat penting." Hal ini membuktikan bahwa organisasi pembelajar bukan satu-satunya faktor penting dalam membangun komitmen pada organisasi guna mempersiapkan sumber daya manusia yang berkualitas.

Sedangkan hal ini bertolak belakang pada kebanyakan hasil penelitian serupa seperti yang dilakukan pada bidang bisnis, yaitu dalam penelitian yang dilakukan oleh Che Rose et al. (2009) "menemukan bahwa adanya terdapat pengaruh antara organisasi pembelajaran terhadap komitmen pada organisasi." Dimana karyawan lebih mengabdi kepada organisasi karena merasa senang (afektif) dan mempunyai nilai yang selaras (normative) sehingga rasa senang dan bangga menjadi bagian dari sebuah organisasi membuat organiasasi memiliki arti khusus untuk mereka.

Pengaruh keterlibatan karyawan terhadap komitmen organisasi

Pada penelitian ini keterlibatan karyawan menunjukan berpengaruh secara signifikan terhadap komitmen organisasi dengan nilai T-statistik sebesar 6,087 hasil nilai PValue 0,005 yang jauh lebih kecil dari nilai alpha 0,05 pada taraf kepercayaan $95 \%$. Hal ini juga ditunjukkan dengan nilai original sampel yang positif yaitu sebesar 0,750 yang menunjukkan bahwa arah hubungan antara X2 dan Y2 adalah positif. Pengaruh positif tersebut juga dapat dibuktikan dengan salah satu indikator pernyataan keterlibatan karyawan memberikan pengaruh sangat kuat adalah pekerjaan yang dikerjaan karyawan merawat sesama manusia dan merupakan pekerjaan yang mulia. Hasil penelitian ini sejalan dengan penelitian yang dilakukan oleh (Zulkarnain and Hadiyani, 2014) "bahwa keterlibatan karyawan berpengaruh terhadap komitmen organisasi disebabkan oleh faktor penting dalam membuat keputusan." Hasil ini membuktikan bahwa keterlibatan karyawan merupakan faktor penting dalam meningkatkan komitmen organisasi.

Pengaruh komitmen organisasi terhadap perubahan organisasi

Pada penelitian ini komitmen organisasi menunjukan berpengaruh secara signifikan terhadap perubahan organisasi dengan nilai T-statistik sebesar 2,263. hasil nilai P-Value 0,024 yang jauh lebih kecil dari nilai alpha 0,05 pada taraf kepercayaan $95 \%$. Hal ini juga ditunjukkan dengan nilai original sampel yang positif yaitu sebesar 0,391 , yang menunjukkan bahwa arah hubungan antara $\mathrm{Y} 1$ dan $\mathrm{Y} 2$ adalah positif. Pengaruh positif tersebut juga dapat dibuktikan dengan salah satu indikator pernyataan komitmen organisasi.. Hasil relevan ini dengan adanya komitmen organisasi dengan perubahan organisasi. Hasil penelitian ini sejalan dengan penelitian yang dilakukan oleh Yunas et.al (2016) yang "menyatakan bahwa komitmen organisasi berpengaruh terhadap perubahan organisasi disebabkan faktor penting dalam komitmen organisasi." Namun tidak sejalan dengan penelitian ismail et.al (2010) menyatakan bahwa komitmen organisasi tidak berpengaruh secara signifikan terhadap perubahan organisasi. Hasil ini membuktikan bahwa komitmen organisasi merupakan faktor penting dalam perubahan organisasi. Dengan adanya komitmen organisasi maka perubahan dalam organisasi dalam berjalan sesuai tujuan organisasi tersebut.

Pengaruh organisasi pembelajaran terhadap perubahan organisasi

Pada penelitian ini organisasi pembelajaran menunjukan tidak berpengaruh secara signifikan terhadap perubahan organisasi dengan nilai T-statistik sebesar 6,212. Hasil nilai P-Value 0,832 yang jauh lebih besar dari nilai alpha 0,05 pada taraf kepercayaan $95 \%$. Hal ini juga ditunjukkan dengan nilai original sampel yang positif yaitu sebesar 0,728 yang menunjukkan bahwa arah hubungan antara X1 dan Y1 adalah positif. Pengaruh positif tersebut juga dapat dibuktikan dengan salah satu indikator 
pernyataan organisasi pembelajar yang tidak memberikan pengaruh sangat kuat adalah kesediaan berbagi informasi terkini terkait kondisi pasien.

Hasil penelitian ini sejalan dengan penelitian Rouzbahani, M.Khazai, E.Farah et. Al (2013) "yang mengemukakan antara organisasi pembelajaran dengan kesiapan organisasi untuk berubah tidak berpengaruh secara signifikan."

Hasil penelitian ini tidak sejalan dengan penelitian yang dilakukan oleh Jafari \&

Kalanaki (2012) yang menyatakan "bahwa organisasi pembelajaran tidak terdapat pengaruh terhadap perubahan organisasi disebabkan faktor penting dalam organisasi pembelajar memiliki banyak dampak pada perubahan organisasi. Hasil ini membuktikan bahwa organisasi pembelajar merupakan faktor penting dalam perubahan organisasi. Untuk tercapainya perubahan organisasi ke arah yang lebih baik maka diperlukan organisasi pembelajaran sebagai wadah terciptanya penggerak yang dibutuhkan dalam perubahan organisasi."

Pengaruh keterlibatan karyawan terhadap perubahan organisasi

Pada penelitian ini keterlibatan karyawan menunjukan pengaruh yang signifikan terhadap perubahan organisasi dengan nilai T-statistik sebesar 2,826 hasil nilai P-Value 0,005 yang jauh lebih kecil dari nilai alpha 0,05 pada taraf kepercayaan $95 \%$. Hal ini juga ditunjukkan dengan nilai original sampel yang positif yaitu sebesar 0,533 yang menunjukkan bahwa arah hubungan antara $\mathrm{X} 2$ dan $\mathrm{Y} 1$ adalah positif. Pengaruh positif tersebut juga dapat dibuktikan dengan salah satu indikator pernyataan keterlibatan karyawan yang memberikan pengaruh sangat kuat adalah pekerjaan saya adalah pekerjaan yang mulia, yakni merawat pasien dengan baik hingga mereka sembuh.

Hasil penelitian ini sejalan dengan penelitian yang dilakukan oleh Khalid et.al (2015) "bahwa keterlibatan karyawan berpengaruh terhadap perubahan organisasi". Namun penelitian ini tidak sejalan dengan penelitian Ferlan (2016) "bahwa keterlibatan karyawan tidak berpengaruh terhadap perubahan organisasi."

\section{E. KESIMPULAN}

Berdasarkan hasil analisis serta pembahasan yang telah diuraikan maka dapat diambil kesimpulan bahwa organisasi pembelajaran berpengaruh signifikan terhadap komitmen organisasi pada RSJPDHK. Hal tersebut menunjukkan bahwa dalam organisasi pembelajaran yang memberikan pengaruh sangat kuat dalam melakukan perubahan organisasi yaitu dengan senantiasa meminta penjelasan kepada atasan jika ada hal yang tidak jelas mengenai pekerjaan sebagai karyawan. Informasi yang jelas dan akurat tentang pekerjaan yang sesuai dengan prosedur maka akan membuat pelayanan semakin lebih baik kepada pasien. Keterlibatan karyawan berpengaruh signifikan terhadap komitmen organisasi pada RSJPDHK. Hal ini menunjukkan bahwa keterlibatan karyawan memberikan pengaruh yang sangat kuat dalam komitmen organisasi yaitu mencintai pekerjaan. Dengan slogan "melayani dengan hati" akan memberikan kenyamanan pasien dalam menjalani pengobatan. Komitmen organisasi berpengaruh signifikan terhadap perubahan organisasi pada RSJPDHK. Hal ini menunjukkan bahwa komitmen organisasi berpengaruh kuat terhadap perubahan organisasi dalam berkomitmen menjaga kerahasiaan data pasien. Dengan demikian dapat memberikan pelayanan kesehatan yang terbaik kepada pasien. Komitmen yang kuat akan menjadikan perubahan organisasi semakin cepat. Organisasi pembelajaran tidak berpengaruh secara signifikan terhadap perubahan organisasi pada RSJPDHK. Hal ini menunjukkan bahwa adanya keinginan perubahan ke arah yang lebih baik antar unit kerja. Perubahan organisasi ini dapat dimulai dengan adanya pelatihan dan 
pendidikan yang lebih berkualitas untuk menuju keunggulan layanan rumah sakit. Keterlibatan karyawan berpengaruh signifikan terhadap perubahan organisasi pada RSJPDHK. Hal ini menunjukkan bahwa adanya dukungan penuh untuk pelaksanaan perubahan yang lebih baik di dalam unit kerja. Salah satu upaya perubahan organisasi yang telah dilakukan oleh manajemen RSJPDHK adalah telah dibentuknya agent of change atau agen perubahan. Dari hal tersebut diharapkan agen perubahan tersebut dapat menjadi penggerak terjadinya perubahan di dalam manajemen RSJPDHK.

"Dari hasil penelitian diatas tampak bahwa perubahan organisasi dipengaruhi secara signifikan oleh organisasi pembelajaran, keterlibatan karyawan dan komitmen organisasi. Hal tersebut menunjukkan bahwa dalam melakukan perubahan organisasi, hal utama yang perlu diperhatikan oleh manajemen adalah menciptakan organisasi pembelajaran yang efektif dengan adanya keterlibatan karyawan dan komitmen yang kuat."

Melihat hasil pencapaian pengaruh organisasi pembelajaran yang menunjukkan bahwa berpengaruh terhadap komitmen organisasi, ternyata karyawan lebih memperhatikan pendidikan dan pelatihan di dalam organisasi. Hal ini ditunjukkan dari koordianasi yang baik antara atasan dan bawahan sehingga menciptakan kerjasama yang baik pula didalam pekerjaan.

Tujuannya ada untuk keberhasilan suatu unit kerja karena secara tidak langsung dipengaruhi oleh unit kerja lainnya serta dapat menyelesaikan pekerjaan secara tuntas. Dengan memahami visi organisasi yakni terdepan dalam pelayanan, pendidikan dan penelitian kardiovaskular dan senantiasa menggali pengetahuan maka sumber daya manusia dituntut untuk dapat mengemukakan ide-ide baru guna perubahan organisasi yang diharapkan ke arah yang lebih baik. Pekerjaan yang ditekuni dapat membantu orang lain sehingga dapat menimbulkan kecintaan terhadap pekerjaan tersebut.

Dalam penelitian ini ditemukan beberapa manfaat yang dijadikan saran, yaitu sebagai berikut :

1. Saran bagi perusahaan RSJPDHK harus mempersiapkan manajemen sumber daya manusia yang lebih unggul untuk dapat menghadapi perubahan. Berbagai hal dapat dilakukan oleh perusahaan demi mencapai tujuan bersama. Perusahaan sebaiknya memberikan pendidikan dan pelatihan kepada seluruh karyawan dengan tujuan pengembangan diri dan pertumbuhan individu. Meningkatkan kualitas kinerja karyawan diperlukan tekad yang besar bagi sebuah perusahaan. Berilah kesempatan kepada seluruh karyawan untuk dapat belajar dan tumbuh menjadi sumber daya manusia yang berkulitas maka produktivitas karyawan pun akan meningkat. Pelatihan yang sesuai serta bersertifikasi standar RSJPDHK setiap tahunnya dengan bidang karyawan tersebut akan menjadikan mereka bersemangat dan lebih produktif dalam bekerja. RSJPDHK sebaiknya melengkapi peralatan yang karyawan butuhkan adalah untuk meningkatkan produktivitas mereka. Perusahaan juga sebaiknya memberikan apresiasi kepada karyawannya yang telah bekerja keras untuk perusahaan agar mereka bahagia dan merasa nyaman. Jika situasi tersebut terbentuk maka karyawan akan lebih berkomitmen. Menciptakan keharmonisan kerja antara atasan dan bawahan dengan keterlibatan karyawan. Membantu karyawan memahami tujuan perusahaan dan pekerjaan yang mereka sedang lakukan. Dengan begitu mereka akan melihat hubungan antara pekerjaan yang mereka lakukan dan kontribusi bagi perusahaan. Untuk komitmen organisasi akan terbentuk dengan sendirinya jika seluruh karyawan telah mendapatkan manfaat yang telah diberikan kepada organisasi atau perusahaan. Dengan kerja keras karyawan dan kepercayaan perusahaan yang diberikan sehingga akan tercapai tujuan perusahaan maka hal itu membuat bangga karyawan dan akan menjunjung tinggi pada komitmen perusahaan. 
2. Dilihat dari hasil penelitian yang terkait dengan keterlibatan karyawan dengan komitmen organisasi memiliki pengaruh hubungan yang cukup signifikan. Oleh karena itu, untuk penelitian kedepannya diharapkan akademisi mengkaji lebih dalam bentuk hubungan antar variabel dan antar dimensi serta dapat mengembangkan penelitian terkait dengan variabel tersebut untuk pengembangan penelitian yang lebih mendalam serta menyeluruh sehingga dapat memperbaiki kekurangan-kekurangan yang terdapat dalam penelitian ini.

\section{DAFTAR PUSTAKA}

Albrecht,S.L. 2010. Handbook of employee Engangement : Perspectives, Issues, Reseach and Practice. United Kingdom: Edward Elgar Publising Lth.

Alwi, Syafaruddin. 2001. Manajemen Sumber Daya Manusia, Strategi Keunggulan Kompetitif. BPFE UGM, Yogyakarta.

Anatan, Lina \& Lena Ellitan. 2009. Manajeman Sumber Daya Manusia Dalam bisnis Modern. Bandung. Alfabeta.

Ardana, Komang, Mudiarta Utama, I Wayan, Ni Wayan Mujiati,. 2012. Manajemen Sumber Daya Manusia . Yogyakarta; Graha IImu.

Ardana, Mujiati dan Utama.2012. Manajemen Sumber Daya Manusia. Yogyakarta, Graha IImu.

Bakker, Arnol.B, Leiter, Michael.P.2010. Work Engangement : A Handbook of Essential Theory and Research. New York : Psychology Press.

Ferdinand, A.2011. Metode Penelitian Manajemen, Semarang: Indoprint. Firmansyah, Yayan. 2016. Pengaruh manajemen perubahan terhadap organisasi pembelajaran serta dampaknya terhadap kinerja pegawai pada PT KAI (Persero) Daop II Bandung. Jurnal Manajemen Bisnis Indonesia, Vol.3, Nomor 3. ISSN 2338-4557.

Gallup.2008. Employee Engangement - What's Your Engangement Ratio?. Gallup Inc.

Georgiades, Stavros, 2015. Employee Engangement in media management : creativeness and organizational development, Neew York. Springer. https://www.researchgate.net/publication/299801362_Employee_Engageme nt_and_Organizational_Change

Hakim, Lukman dan Eko Sugiyanto. 2018. Manajemen perubahan organisasi sebagai upaya peningkatan kinerja perusahaan di industri batik laweyan surakarta.issn: 1410-4571, E-ISSN:2541-2604

Hariandja, Marihot Tua Effendi, 2012. Manajemen Sumber daya manusia: Pengadaan, Pengembangan, pengkompensasian, dan Peningkatan Produktitivas pegawai. Jakarta: Grasindo.

Harper, S.C., anda D.J. Glew. 2008. Is your organization learning-impaired?. Industrial Engineer40(4) : S26.

Jones, Jhon and DeAnne aguirre and Mathew Calderone, strategy+business, "10 Principles of Change Management"Organizations \& People, 15 April 2004, diakses 3 Maret 2019. https://www.strategy-business.com/article/rr00006?gko=643d0 
Kasali, Renald. 2015. Change! Manajemen Perubahan dan Harapan. Jakarta : PT.Gramedia Pustaka Umum

Khalid, Ambar et el (2015) Relationship Between Organizatinal Commitment, Employee Engangement and career satisfaction : A Case Of University Of Gujrat, Journal of Bussiness and Social Science, Vol.3 No.11

Kotter, John P (2011) Leading Change, Harvard Business School Press. Ortenblad,2001. On differences between organizational learning and learning organization, The learning organization, Vol 8,No.3, MCB Univercity Press ISSN 0969-6474

Lesmana, R., Sunardi, N., \& Kartono. The Effect of Financing and Online Marketing on MSMEs Income Increasing at Intermoda Modern Market BSD City Tangerang Selatan. American Journal of Humanities and Social Sciences Research (AJHSSR), 5(7), 25-34

Lesmana, R., Sunardi, N., Hastono, H., \& Widodo, A. S. (2021). Perceived Quality Membentuk Customer Loyalty via Brand Equity pada Pengguna Smartphone Merek Xiaomi di Tangerang Selatan. Jurnal Pemasaran Kompetitif, 4(2), 157-167

Lesmana, R., Sutarman, A., \& Sunardi, N. Building A Customer Loyalty Through Service Quality Mediated by Customer Satisfaction. American Journal of Humanities and Social Sciences Research (AJHSSR), 5(3), 38-45

Luscombe dan Biggs. 2013: Essential elements for recruitment and retention: Generation Y. Education + Training. Emerald Group Publishing Limited 00400912Vol. 55 No. 3. HIm: 272-290

Luthans, Fred.2012. Perilaku Organisasi edisi 10. Yogjakarta : Penerbit ANDI. Luthans, F., Peterson, S.J. (2002). Employee engagement and manager self- efficacy: implications for managerial effectiveness and development. Journal of Management Development Vol 21, No. 5, pp: 276-287

Lyons, S. (2004). An exploration of generational values in life and at work. ProQuest Dissertations and Theses,441-441. Retrieved from http://ezproxy.um.edu.my/docview/305203456?accountid=28930

Marsick, Victoria,J., Watkins, Karen.E.2003, The Diminsion of a learning Organization Questionnaire (DLOQ) : Introducing to the Issue Exaining DLOQ Use Over a Decade. Advances in Developing Human Rrsouces, 15,127

Paul, Mukucha. "The Mediation Effects of Perceived Service Quality in The Relationship between Employee Satisfaction and Customer Satisfaction", Journal of Studies in Accounts and Economics, Vol. 1 No. 3, pp. 9-16, 2013.

Prihartini, T. 2013. Pengaruh keterlibatan kerja dan komitmen organisasi terhadap manajemen perubahan (studi pada divisi mineral PT Harita Group). Jurnal IImiah Manajemen \& Akuntansi "IMAGE" Volume XVI No.39.

Primasary, Ledy. 2011. Proses Manajemen Perubahan dalam Program Transformasi Bisnis : "Studi Kasus PT Tripatra pada tahun 2010-2011". http://lib.ui.ac.id/detail?id=20292010\&lokasi=lokal

Purnama, M. Dan Budiharjo A. 2009. Peran Budaya Pembelajaran dan Knowledge Management. Jurnal Manajemen Bisnis Volume 1 No.3. Prasetya Mulya Business School. Jakarta 
Robbins dan Judge, 2008, Perilaku Organisasi, Organizational Behavior. Edisi 12. Jakarta : Salemba Empat

Robbins dan Judge, 2011, Perilaku Organisasi / Organizational Behavior.. Edited by Dono Sunardi. Translate by Diana Angelica. Jakarta : Salemba Empat

Robbins, Stepen. (2007) Perilaku Organisasi: Terjemahan: Benyamin Molan. New Jersey Prentice Hall, Inc.

Robbins, Stephen \& Judge, Timothy. (2008). Perilaku Organisasi: Organizational Behavior. Jakarta: Salemba Empat.

Robbins, Stephen P. Judge, Timothy A. Judge. 2015. Perilaku Organisasi (Organizational Behavior)Terj: Ratna Saraswati Dan Febriella Sirait Edisi 16. Jakarta: Salemba Empat.

Robbins, Stephen P. Judge. 2005. Organizational Behavior Eleventh Edition. New Jersey: Pearson.

Sandjojo,N. 2014. Metode Analisis Jalur dan Aplikasinya. Edisi Revisi. Fakultas IImu Komputer. Universitas Pembangunan Nasional "Veteran" Jakarta.

Santoso, Singgih, 2015, Amos 22 untuk Struktural Equation Modelling Konsep Dasar dan Aplikasi, Gramedia: Jakarta

Sayyed, M. A., Mohsen, S., dan Hossein, M. 2012, Investigating Employee's Attitude Toward Organization, Organizational Climate and Employee's engangement as Antecedents of Organizational Citizenship Behavior. Australian Journal of Basic and Applied Sciences. Vol 6 No.8, Hal.384-393.

Scheimann, W.A. (2011). Alignment, capability, engagement: pendekatan baru talent management untuk mendongkrak kinerja organisasi. Penerjemah : Setyo Untoro. Jakarta. Penerbit PPM

Senge, Peter M. 1990. The Fifth discipline : The art and Practice of the learning organization New York : Doubleday.

Senge, Peter M. 2006. Educational Leadership. United State : John Wiley \& Sons, Inc.

Sobirin, A. 2014. Konsep dasar perubahan dan perubahan organisasi, EKMA4564/Modul 1. http://repository.ut.ac.id/4840/1/EKMA4565M1.pdf

Solimun, 2018. Metode Statistika Multivariart. Cetakan keempat. Malang:UB Press.

Sugiyono, 2017. Metode Penelitian: Kuantitatif, Kualitatif, dan R\&D, Cetakan ke-26. Bandung:Alfabeta.

Sumardjo, Mahendro dan Donni Juni Priansa, 2018, Manajemen Pengembangan Sumber Daya Manusia Konsep-konsep kunci. Bandung: Alfabeta

Sunardi, N., \& Lesmana, R. (2020). Konsep Icepower (Wiramadu) sebagai Solusi Wirausaha menuju Desa Sejahtra Mandiri (DMS) pada Masa Pandemi Covid19. JIMF (Jurnal IImiah Manajemen Forkamma), 4(1).

Tanjungsari, Retry Tyas. 2012. Analisis Penerapan Organisasi Pembelajar pada Rumah Sakit Sentra Medika Depok. Jurnal IPB.

Watkins, Karen. E.O'neil, Judy.2014. the Dimensions of the learning organization questionnaire (the DLOQ) : a Nontechnical Manual. Advances in Developing 
Human.15(2), 137-147

Wibowo,2016, Manajemen Perubahan. Edisi ketiga,2018. Jakarta : Penerbit Raja Grafindo.

Winardi, J, 2015. Manajemen perubahan (management of change). Cetakan keenam, 2015. Jakarta :Penerbit Kencana Prenada Media Group.

Yusthisia, A Budi. 2017. Analisis implementasi manajemen perubahan terhadap kepemimpinan dan budaya kerja serta Pengaruhnya pada kinerja karyawan di Bank Jatim Banyuwangi.

Zainal, dkk, 2014, Manajemen sumber daya manusia, cetakan ke-6, PT.Raja Grafindo Persada, Jakarta 